\title{
Análise microgenética do funcionamento cognitivo de crianças por meio do jogo matix
}

\author{
Microgenetic analysis of the cognitive functioning \\ of children by means of the matix game
}

\author{
Christiany Maria Bassetti CAVALCANTE² \\ Antonio Carlos ORTEGA²
}

\begin{abstract}
Resumo
Este trabalho teve por objetivo analisar, em um contexto microgenético, o funcionamento cognitivo de crianças por meio do jogo Matix. Participaram desta pesquisa quatro alunos da quarta série do Ensino Fundamental. Na primeira etapa, cada criança jogou três partidas para conhecer e explorar o jogo. Na segunda, os participantes formaram duplas que competiram entre si. Em seguida houve um rodízio entre eles, até que todos tivessem formado duplas e competido. Na terceira etapa, os participantes formaram uma dupla que resolveu situações-problema. Na última, cada participante jogou uma partida para avaliar que nível de compreensão cada um conseguiu alcançar após passar pelo processo de interação social. Os resultados indicaram uma evolução dos níveis de compreensão do sistema lógico contido no jogo Matix em todos os participantes. Constatou-se que o progresso cognitivo parece estar associado às condições cognitivas de cada sujeito e à possibilidade de sua inter-relação com os parceiros.
\end{abstract}

Unitermos: Construtivismo. Jean Piaget. Jogos. Processos cognitivos.

\begin{abstract}
The objective of this work was to analyze, in a microgenetic context, the cognitive functioning of children by means of the Matix game. Four fourth-grade Elementary School students took part in this research. In the first stage, each child played three games so as to get to know and explore the game. In the second stage, the participants worked in pairs which competed against each other. Then they rotated until everyone had formed pairs and taken part. For the third stage, the participants formed one pair who resolved problem-situations. In the final stage, each participant played a game so as to evaluate the level of understanding achieved by each, after going through the process of social interaction. The results indicated progress in the level of comprehension of the logical system within the Matix game, for all the participants. It was ascertained that cognitive progress seems to be associated with the cognitive conditions of each subject, and with the possibility of inter-relationship with their partners.
\end{abstract}

Uniterms: Constructivism. Piaget Jean. Games. Cognitive processes.

\section{$\boldsymbol{\nabla V \boldsymbol { V }}$}

1 Artigo elaborado a partir da dissertação de C.M.B. CAVALCANTE, intitulada "Análise microgenética da interação social e do funcionamento cognitivo de crianças por meio do jogo Matix". Universidade Federal do Espírito Santo. 2006. Apoio financeiro: Coordenação de Aperfeiçoamento de Pessoal de Nível Superior.

2 Universidade Federal do Espírito Santo, Programa de Pós-Graduação em Psicologia. Av. Fernando Ferrari, s/n., Goiabeiras, 29060-900, Vitória, ES, Brasil. Correspondência para/Correspondence to: C.M.B. CAVALCANTE. E-mail: <cmbcavalcante@uol.com.br>. 
Em vários momentos de seu percurso como epistemólogo, Piaget ressaltou a importância das transmissões socioculturais e das interações sociais para a construção do conhecimento, indicando, assim, ser esse tema uma condição necessária para o desenvolvimento cognitivo. De acordo com Piaget (1924/1967), a vida social contribui para que os processos mentais se tornem reversíveis, determinando, então, o surgimento do raciocínio lógico. Ele argumenta que o confronto de pensamentos de uns com os outros produz a dúvida e a necessidade de provar, sendo necessário, para isso, o compartilhamento social do pensamento.

A relação entre os indivíduos e o grupo social é, para o autor, a de uma otalidade relacional, na qual as operações individuais e a cooperação constituem um todo indissociável. O indivíduo é resultante de várias interações dependentes do meio; não é, portanto, um elemento independente. No campo do conhecimento, as operações individuais e as que proporcionam a cooperação cognoscitiva também são solidárias. 0 indivíduo possui construções intelectuais na medida em que participa de interações coletivas.

O desenvolvimento mental do indivíduo, segundo Piaget (1945/1973), é acelerado pela transmissão social, pois a construção operatória, que traduz em estruturas mentais as potencialidades proporcionadas pelo sistema nervoso, apenas se efetua devido às funções de interações dos indivíduos. É a interdependência entre os fatores mentais e as relações interindividuais que contribui para a construção progressiva das operações intelectuais. A relação interindividual produz transformações nos sujeitos individualmente: um sujeito contribuindo para a transformação do outro e vice-versa.

Apesar de Piaget ter destacado a necessidade das transmissões e interações sociais para a construção cognitiva, ele não estudou sistematicamente como estes fatores atuariam no processo. Mas, acreditando que o construtivismo piagetiano proporcione condição para este estudo, um grupo de investigadores da área da psicologia social genética, na década de setenta, iniciou suas pesquisas sobre o papel da interação social na construção cognitiva.

Doise e Mugny (1981) e Perret-Clermont (1984) realizaram pesquisas com o objetivo de estudar as realizações individuais de crianças após elas terem 450 participado de sessões de atividade em grupo. A partir desses trabalhos, os autores desenvolveram a concepção de conflito sócio-cognitivo que aconteceria em situações de pequenos grupos de crianças.

Dentre esses estudos, sublinha-se o trabalho de Perret-Clermont (1984). Para a autora, a interação social de crianças, em algumas condições, pode possibilitar o progresso do desenvolvimento cognitivo, mas para que isso aconteça é necessário que o sujeito possua determinada competência cognitiva, para que, ao participar de interações sociais, seja suscitado nele um processo de reestruturação.

Para compreender como o processo de interação social pode contribuir para este progresso, é fundamental, segundo Gilly, Fraisse e Roux (1992), considerar as condições de apresentação e as características da tarefa, o tipo de funcionamento cognitivo individual gerado e o tipo de funcionamento sóciocognitivo dos parceiros. Para eles, há uma estreita e indispensável relação entre esses fatores.

Os estudos realizados por Moro (1987, 1991, 2000) sobre o papel da interação social de crianças no processo de aprendizagem foram referência para este estudo. A autora define a interação social

\footnotetext{
... em termos das relações tecidas pelos pares infantis entre suas realizações de execução/solução das tarefas de aprendizagem, e entre elas com as intervenções do adulto que propõe essas tarefas. Assim, refere-se ao fato de que as realizações cognitivas (estratégias cognitivas) de cada sujeito marcam-se mutuamente, e marcam e deixam-se marcar pelo que o adulto faz (2000, p.299).
}

Para a ocorrência da aprendizagem, a autora considera que, no mínimo, é necessário as crianças realizarem tarefas umas com as outras em pequenos grupos, sob a orientação de um adulto, pois, dessa forma, há a possibilidade do aparecimento de confrontos e pontos de vistas diferentes na aquisição do que é aprendido.

Em estudo anterior, Cavalcante, Ortega e Rodrigues (2006) realizaram um trabalho que teve por objetivo analisar as formas de interação social de crianças em situações de competição e não-competição, por meio do jogo Matix. Os resultados indicaram a existência de sete categorias de interação na situação de competição: execução isolada; execução isolada com negação; execução isolada com comentário; elaboração 
aquiescente; cooperação; exclusão e confrontação. Entretanto, houve uma variação dessas categorias na situação de não-competição, indicando que as formas de interação social de crianças estão relacionadas com as características da situação-problema, do funcionamento cognitivo e da dinâmica sócio-cognitiva apresentada.

Em continuidade àquele, a interação social continua a ser tema do estudo dos autores, mas agora com o objetivo de realizar uma análise microgenética do funcionamento cognitivo (Inhelder \& Cellérier, 1996) - caracterizado pela utilização de procedimentos e estratégias dos participantes - por meio do jogo Matix, durante o processo de interação social de crianças.

\section{Método}

\section{Participantes}

Os participantes da pesquisa foram quatro meninos: Lucas, Guido, Dario e João ${ }^{3}$, com as idades respectivas de 10 anos e 7 meses; 10 anos; 10 anos e 2 meses; 10 anos e 2 meses, que cursavam a quarta série do Ensino Fundamental de uma escola pública da cidade de Vitória (ES).

A escolha por crianças na faixa etária de 10 anos foi baseada em estudos de Piaget (1935/1998) sobre a evolução do trabalho em grupo. O número de quatro participantes justifica-se por proporcionar uma análise microgenética dos procedimentos e das estratégias cognitivas de cada criança e da compreensão do desempenho delas no jogo. Os quatro participantes foram selecionados por sorteio.

\section{Instrumentos}

A pesquisa foi realizada utilizando como instrumento o jogo de regras Matix. Esse jogo é, ainda, pouco pesquisado (Marco, 2004; Torres, 2003, 2005), e não foi encontrado nenhum trabalho relacionando-o à interação social.

Torres (2003), em sua pesquisa Raciocínio lógicomatemático de crianças nojogo Matix, constatou que este jogo permite avaliar como os participantes constroem seus conhecimentos a cada situação-problema proposta e, também, analisar os procedimentos e as estratégias dos participantes, considerando as dimensões lógica e matemática do raciocínio.

Na perspectiva lógica do raciocínio, o jogo permite analisar e desenvolver diversas operações mentais necessárias para o bom desempenho, como a capacidade de antecipação de jogadas, a coordenação entre as ações, a dedução e a inferência.

Na perspectiva matemática do raciocínio, o Matix permite avaliar e desenvolver as operações matemáticas utilizadas pelo participante ao lidar com a positividade e negatividade dos números, durante a partida e na contagem final dos pontos.

Em pesquisas de intervenção, tal como a realizada por Marco (2004), esse tipo de jogo pode, além de favorecer o desenvolvimento do pensamento matemático e auxiliar no processo de generalização matemática, promover o desenvolvimento do raciocínio, exercitando e estimulando um pensar com lógica e critério, interpretando informações, buscando soluções, levantando hipóteses e coordenando diferentes pontos de vista (Petty, 1995).

Assim, o jogo Matix propicia o trabalho com estratégias de antecipação de jogadas e a reflexão sobre elas, possibilitando a escolha da melhor jogada a ser feita. Além disso, ele promove a utilização da análise do jogo a todo o momento da partida, pois o jogador tem que pensar tanto na sua jogada quanto na do adversário.

Esse jogo é indicado para crianças a partir de onze anos de idade, por trabalhar a noção matemática de números inteiros, mas já se constatou que, apesar de não conhecerem o conceito de números inteiros, crianças entre oito e dez anos conseguem lidar intuitivamente com esta noção (Marco, 2004; Torres, 2003).

O Matix é um jogo de tabuleiro, criado na Alemanha, e possui duas versões: uma com 36 casas (Figura 1) e outra com 64 casas. Optou-se pela versão de 36 casas em razão do tempo disponível das crianças para a pesquisa. 


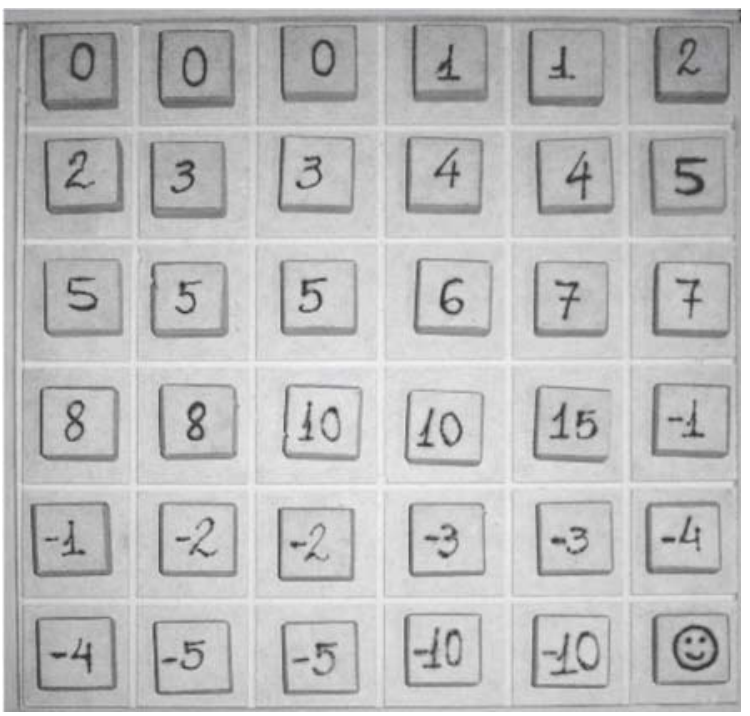

Figura 1. Foto do jogo Matix.

As casas do jogo são preenchidas por um número correspondente de peças, que são assim compostas: 0 (três peças); 1, 2, 3 e 4 (duas peças de cada); 5 (quatro peças); 6 (uma peça); 7,8 e 10 (duas peças de cada); 15 (uma peça); -1,-2,-3,-4,-5 e-10 (duas peças de cada); e uma peça-coringa. O objetivo do jogo consiste em retirar uma a uma as peças do tabuleiro e conseguir o maior número de pontos. Para isso, somam-se as peças de valor positivo e subtraem-se as de valor negativo. Deve ser jogado por, no mínimo, duas pessoas: uma joga no sentido horizontal (linhas) do tabuleiro, e a outra, no sentido vertical (colunas).

Inicia-se o jogo com todas as peças distribuídas aleatoriamente sobre as casas do tabuleiro, viradas para baixo. Após a decisão de quem inicia a partida, é feita a escolha do sentido (horizontal ou vertical) em que cada um jogará, e todas as peças são viradas para cima.

Cada jogador movimenta a peça-coringa, no sentido escolhido, até a casa cujo número deseja retirar para si. Assim, o primeiro jogador retira a peça-coringa e, em seguida, escolhe um número na mesma linha (se escolheu jogar na horizontal) ou coluna (se preferiu a posição vertical), substituindo-o pela peça-coringa.

O segundo jogador deverá, necessariamente, escolher outro número na mesma linha ou coluna em que a peça-coringa foi colocada e retirá-la, substituindo-a, também, pela peça-coringa. A partida prossegue com jogadas alternadas entre os dois jogadores até o final da partida.
O jogo termina quando todas as peças forem retiradas ou quando a peça-coringa cair em uma linha ou coluna onde não haja mais nenhuma peça. Vence a partida quem tiver mais pontos.

\section{Procedimentos}

A pesquisa foi realizada em uma sala oferecida pela escola e no mesmo período no qual as crianças estudavam, sem perdas do conteúdo escolar. Aconteceu em quatro etapas: na primeira etapa, cada um dos participantes jogou três partidas com a experimentadora, com o objetivo de conhecer e explorar todos os aspectos do jogo. A partir dos dados obtidos das estratégias expostas pelos participantes, e da observação das jogadas efetuadas por eles na terceira partida, foi realizada uma avaliação do nível de compreensão do sistema lógico do jogo; esses níveis foram baseados nos propostos porTorres (2005) para o jogo Matix.

Na segunda etapa, os quatro participantes formaram duplas entre si por sorteio e competiram em três partidas. Após o término dessas três partidas, houve mudança de parceiros entre as duplas, que novamente competiram, jogando mais três partidas. A mudança de parceiros ocorreu até que todos os participantes formassem duplas entre si. O objetivo desta etapa foi verificar a maneira de jogar de cada um dos participantes durante o processo de interação social na dupla durante o jogo, ou seja, em uma situação de competição.

Naterceira etapa, os participantes foram divididos em duplas por sorteio, sendo que cada um apenas formou uma dupla. Cada dupla resolveu três situaçõesproblema propostas pela experimentadora. Após cada resolução das situações-problema, a experimentadora formulou questões para poder analisar os procedimentos e as estratégias cognitivas construídas pelos participantes, ao interagir para encontrar uma resposta ao problema. Pretendeu-se, nesta etapa, avaliar a maneira de jogar de cada um dos participantes enquanto interagiam na busca de uma solução ao problema, mas agora em um contexto de não-competição.

Na quarta etapa, cada um dos participantes jogou, novamente, com a experimentadora. Foi realizada uma partida para avaliar se houve progresso no nível de compreensão do sistema lógico do jogo Matix de 
cada criança, tendo como parâmetro a avaliação feita na primeira etapa.

\section{Análise dos dados}

Todas as etapas do procedimento de coleta de dados foram gravadas em vídeo e áudio e, posteriormente, transcritas. Houve o registro escrito de todas as jogadas realizadas pelos participantes em folha de protocolo de registro própria, como, também, de observações feitas pela pesquisadora no transcorrer da investigação. Desta maneira, pôde-se realizar uma análise microgenética dos procedimentos e das estratégias usadas pelas crianças no jogo.

Para isso, partiu-se dos níveis de análise sugeridos por Torres (2005). A autora propõe três níveis de pensamento, que se expressam como condutas de regulação. Contudo, como esta pesquisa não teve como objetivo analisar os processos de regulação dos participantes, considerou-se que seria mais adequado realizar uma leitura desses níveis em uma perspectiva que proporcionasse verificar o nível de compreensão obtido pelos participantes no sistema lógico contido no jogo Matix. Assim, foram estipulados os seguintes níveis de compreensão:

Nível l: o sujeito não compreende a distinção entre peças de valores positivos e negativos; evita as de valores negativos, perseguindo as de valores positivos. Há a realização de jogadas aleatórias, sem o estabelecimento de relações entre as peças das linhas e colunas do tabuleiro; quando ocorre antecipação é de, no máximo, uma jogada futura, no final do período. As partidas não duram muito tempo, pois não há a retirada de todas as peças do tabuleiro. A contagem é realizada de maneira aleatória, utilizando a soma e a subtração. 0 sujeito organiza as peças em ordem crescente, não havendo a separação das peças de valores positivos e negativos, com a soma de todos os números. Separação das peças de valores positivos e negativos, ocorrendo depois a contagem uma a uma. Utilização dos dedos no auxílio da contagem.

Nível II: o sujeito compreende a distinção entre peças de valores positivos e negativos; as de valor negativo não são evitadas em algumas jogadas, mas ainda há uma preferência por não pegá-las. Ocorre, neste nível, o estabelecimento de relações entre as peças das linhas e colunas do tabuleiro, mas ainda há a realização de uma pequena quantidade de jogadas aleatórias. 0 sujeito antecipa de uma a duas jogadas futuras, e tem uma maior preocupação com as estratégias no jogo. Há a observação esporádica das tendências de estratégias adotadas e dos erros cometidos pelo jogador adversário. As partidas duram mais tempo, pois há a retirada de quase todas as peças do tabuleiro. A contagem das peças ocorre durante ou depois da partida, com agrupamentos a cada dez pontos.

Nível III: o sujeito já não realiza jogadas aleatórias; ele estabelece relações entre as peças das linhas e colunas do tabuleiro, compreende a necessidade de ficar com peças de valor negativo em algumas jogadas para que o jogador adversário não obtenha muitos pontos e antecipa, na maioria das vezes, duas ou mais jogadas futuras. Há constante observação das estratégias adotadas e dos erros cometidos pelo adversário, e as partidas terminam com a retirada de todas as peças do tabuleiro. A contagem das peças ocorre durante a partida, com agrupamentos a cada dez pontos; cancelamento de peças de valores iguais, positivos e negativos; ou agrupamento de peças de valor positivo ou negativo igual, multiplicado pelo número de peças.

Por meio da análise microgenética, procurouse verificar, em cada participante, o processo funcional que estava em curso na resolução dos problemas contidos no jogo. Para isso, fez-se necessário o estudo de caso. Para proceder à análise dos níveis de compreensão do sistema lógico contido no jogo Matix, foram considerados: 1) o desempenho no jogo, observando: a) o planejamento das ações, pela intencionalidade e dedução, b) as antecipações de jogadas futuras e c) a coordenação entre as ações do sujeito e as do adversário; 2) as verbalizações espontâneas das crianças ocorridas durante as partidas e nas respostas às questões formuladas.

\section{Resultados}

Os resultados obtidos na análise do estudo de caso realizado com cada um dos participantes da pesquisa permitiram verificar que todos os participantes, considerando o percurso particular de cada um, evoluíram em seus procedimentos e suas estratégias para jogar o Matix. Eles avançaram, gradativamente, no modo 
de planejar cada vez mais suas ações; passaram de jogadas aleatórias, sem planejamento, a ações planejadas, considerando, na maioria das vezes, a intencionalidade e a antecipação, por dedução, das jogadas. Conseguiram avançar de jogadas sem antecipação a jogadas com uma, duas ou mais antecipações.

Na primeira etapa da pesquisa, os participantes, com o objetivo de ganhar o jogo, pensavam que apenas suas ações eram suficientes, por isso buscavam somente as peças de maior valor. Não compreendiam a necessidade da interdependência de suas ações com as do adversário, e, com isso, não observavam a atuação dele e não percebiam que o outro jogador poderia obter mais pontos que eles. Com o processo de interação, passaram a compreender a importância do adversário para o objetivo do jogo, e passaram a não the ceder mais pontos e a interferir em suas jogadas, procurando fazer com que o opositor não conseguisse pontos.

Assim, todos os participantes progrediram no seu modo de jogar; avançaram de um nível mais simples para um nível mais complexo de compreensão do sistema lógico contido no jogo Matix. Guido e João iniciaram no nível I e avançaram para o nível II; Lucas iniciou no nível II e conseguiu evoluir para o nível III; e Dario, apesar de permanecer no nível II, no qual começou, evoluiu na compreensão do jogo, ampliando suas estratégias e incorporando novos procedimentos para jogar bem, encontrando-se em um período de transição. A Figura 2 demonstra este progresso.

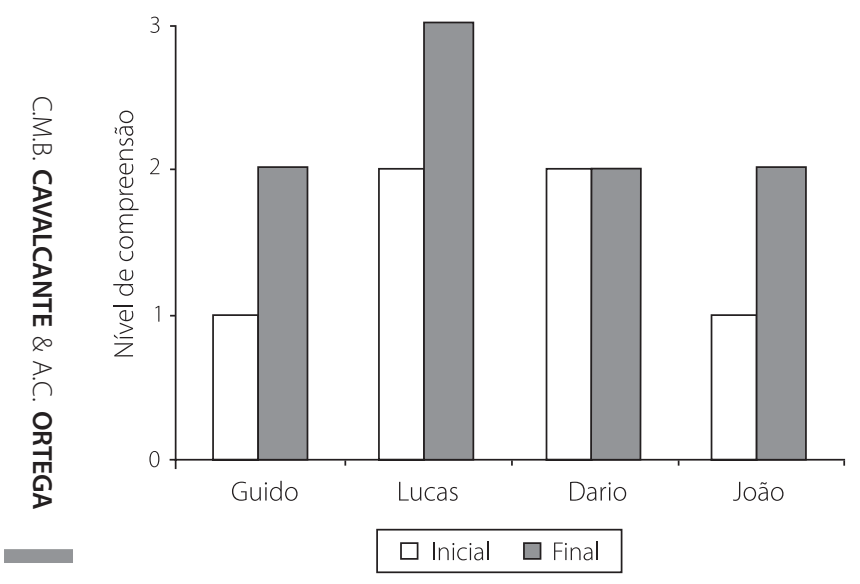

454 Figura 2. Evolução dos níveis de compreensão dos participantes.
Devido aos limites de extensão deste texto e com o objetivo de ilustrar a análise microgenética que possibilitou verificar o funcionamento cognitivo de cada uma das crianças estudadas, especificado pelos procedimentos e estratégias utilizadas por elas em todas as etapas da pesquisa, optou-se por apresentar o relato de caso de apenas um participante.

\section{Caso Lucas}

Lucas compreendeu, na primeira etapa da pesquisa, a distinção entre as peças de valores positivos e negativos desde a primeira partida, não apresentando dúvidas quanto a isso. E, no decorrer desta etapa, pôdese logo perceber uma evolução no seu modo de jogar.

Na primeira partida, ele começou com jogadas rápidas, não ocorrendo nenhum planejamento de suas ações, nem antecipação de jogadas futuras. Não havia estabelecimento de relação entre as peças das linhas e as das colunas; jogava de forma independente, não coordenando suas jogadas com as do adversário. Buscava apenas os números mais altos da fileira em que jogava, e não previa o que resultava de sua jogada. A partir de seus procedimentos, pôde-se verificar que sua estratégia de jogo, nesta partida, era somente a busca pelas peças positivas de maior valor, rejeitando as de valor negativo; não havia a preocupação com a jogada do outro.

A duração da partida foi curta e não ocorreu a retirada de todas as peças do tabuleiro. Lucas não separava as peças de números positivos e negativos nem durante nem depois do término da partida; ele contava, primeiro, os números positivos, e depois, os negativos, e fazia a subtração.

Na segunda partida já começaram a ocorrer algumas mudanças no procedimento de jogar de Lucas. Ele começou a planejar suas ações, considerando a intencionalidade e a antecipação de uma jogada futura. Na 5a jogada, ele pegou o 3 ao invés do 5, maior número da fileira, para não dar o 15 (maior peça do jogo) ao adversário. Parece que sua estratégia, nesse momento, foi não deixar que o outro pegasse a peça 15, o que ele confirmou em comentário feito após o término da partida. Outra estratégia usada foi procurar, em algumas situações, colocar o outro jogador em fileiras com números positivos baixos e negativos. Lucas, nesta partida, começou a não mais rejeitar as peças negativas 
em algumas jogadas; por exemplo, na 7a jogada, para que o adversário não pegasse o 15, ele não pegou o único número positivo da coluna e aceitou pegar a peça de valor negativo -2. Houve uma evolução no seu modo de jogar, mas ainda com certa instabilidade em suas ações; ora planejava e antecipava a jogada, ora jogava rapidamente, não ocorrendo antecipação. Realizou antecipações de apenas uma jogada.

Na terceira partida, verificou-se que Lucas tinha apresentado um avanço na compreensão do jogo. Passou a planejar suas ações, considerando a intencionalidade e as antecipações das jogadas, e não as realizava mais de forma rápida e aleatória. Relacionava as peças da coluna e da linha. Havia uma interdependência entre suas ações e as do adversário, pois analisava todas as possibilidades de jogadas que tinha e antevia as conseqüências delas para a jogada do adversário. Por exemplo: na 3a jogada, Lucas pegou a peça 5, mas não a 8 (maior número da fileira), pois antecipou que daria o 15 para o adversário. Essa mudança já vinha ocorrendo na segunda partida, mas de forma instável; neste momento ela se estabeleceu de maneira mais constante.

Mas, na estratégia de não deixar o adversário pegar o 15, Lucas não percebeu que em muitas jogadas acabou perdendo pontos, pois apenas antecipou aquela jogada, demonstrando que realizava apenas uma antecipação futura. Ele não compreendia ainda que, em algumas jogadas, seria melhor deixar o adversário pegar o 15, pois perderia menos pontos. Exemplo: Lucas, na 9a jogada, escolheu o número 2 e cedeu o 10, mas não pegou o 8, pois daria o 15. Não compreendeu que perderia mais pontos com esta jogada. Pegando o 2, ele ficaria, na próxima jogada, em uma fileira com a peça 0 e outras de valor negativo. Se tivesse pegado o 8, daria o 15, mas nas jogadas posteriores poderia pegar o 5 e o 10, ficando com mais pontos. Pela observação de suas ações, parecia que o que ele tinha como intenção era não permitir que o outro pegasse o 15, mesmo que perdesse muitos pontos, conseqüência que demonstra falta de compreensão. Ele dizia:"vai, pega o 10, mas o 15 não".

Durante a realização da partida, Lucas continuou separando as peças de números positivos e negativos; quase no final, contou quantos pontos negativos possuía. Após o término da partida, ele contou os números positivos que davam a soma dos negativos e realizou o cancelamento das peças. Depois contou o restante dos pontos positivos.
Pela análise dos procedimentos e estratégias adotados por Lucas na terceira partida, verificou-se que ele se encontrava no nível II de compreensão do sistema lógico contido no jogo Matix.

Na segunda etapa da pesquisa, analisou-se como foi o desenvolvimento do desempenho de Lucas em cada dupla de que participou. A primeira dupla foi formada por Lucas e Dario. Logo no início da primeira partida, ele demonstrou jogar de maneira intencional, conseguindo antecipar duas jogadas futuras; na $1^{\text {a }}$ jogada, pegou uma peça, o 7, e colocou os adversários em uma fileira com números negativos e apenas um positivo, sendo que este Ihe proporcionaria o 10 na jogada seguinte. Também realizou a interdependência entre suas ações e as do adversário. Depois de ter analisado todas as possibilidades dos adversários e previsto que qualquer jogada feita por eles Ihe daria número alto, Lucas disse: "qualquer jogada que vocês fizerem vai ser boa para nós". Esse comentário indica que ele compreendia que as ações de um jogador, no jogo Matix, são dependentes das ações do outro.

Todas as jogadas de Lucas já apresentavam intencionalidade nesse momento, mas as jogadas com duas antecipações eram, ainda, inconstantes; ora ele realizava duas antecipações, ora uma. Com o decorrer das partidas, verificou-se que jogadas com duas antecipações se tornaram mais constantes, chegando a ocorrer jogadas com três, quatro e seis antecipações, mas de forma ocasional. Na 6a jogada da segunda partida, ele mostrou para o parceiro a antecipação de uma jogada, e disse: "se você pegar esse (5), eles vão pegar esse (10), a gente vai para cá (3) e eles vão ter que pegar o 1 ou o 0; se eles pegarem o 0 a gente pega o 10; se pegarem o 1, a gente pega o 15". Lucas realizou quatro antecipações.

Na maioria das vezes, Lucas esteve atento às estratégias adotadas e aos erros cometidos pelos adversários, conseguindo fazer algumas deduções. Na ga jogada da primeira partida, Lucas percebeu o erro cometido por João, e disse: "ele deu o 15 para mim de graça, podiam ter ido ao outro 5, deram o 15 de graça". Algumas vezes ele previa que jogada os adversários iam fazer, e dizia para o parceiro: "ele vai pegar o 3". Em outras, ele percebia a estratégia usada pelos opositores, e Ihes dizia: "vocês acham que eu vou cair nessa, né?" (ele percebeu que os adversários o colocaram em uma 
fileira com apenas peças negativas, de maneira que a menor peça negativa cederia o 15). Lucas ainda tinha por estratégia proteger o 15, mas conseguiu perceber, em alguns momentos, que the seria mais vantajoso cedê-lo ao adversário do que perder muitos pontos. Na 8a jogada da terceira partida, ele pegou o 6 e cedeu o 15, mas depois pegou o 10, e disse:"pode pegar o 15 que eu não quero nem saber, pega o 15 que eu pego o 10 depois".

Na dupla com Dario, Lucas continuou a separar as peças positivas e negativas na partida, mas somente fez a contagem dos pontos durante o jogo na terceira partida. Ele não realizou mais o cancelamento dos pontos negativos com os positivos. Ele contou os pontos positivos e Dario os negativos. Na contagem final, ou Lucas fez a subtração das peças, ou Dario realizou a diminuição dos números negativos, um a um, da soma dos positivos.

Após o processo de interação com o parceiro, Lucas ainda se encontrava no nível II de compreensão do jogo, mas já antecipando duas jogadas de forma constante, atento à estratégia e aos erros cometidos pela dupla adversária, e conseguia perceber, em alguns momentos, que sua estratégia de não ceder o 15 não era sempre vantajosa. Apesar de estar no mesmo nível, ele conseguiu evoluir sua compreensão em relação a alguns aspectos.

A segunda dupla foi formada por Lucas e João. Nessa dupla, Lucas, em alguns momentos, realizou três antecipações, mas ainda predominavam jogadas com uma ou duas antecipações. Continuou com a estratégia de busca e proteção do 15, conseguindo abandoná-la em algumas situações; em outras, ele acabava perdendo pontos por não cedê-lo ao adversário. Apesar de haver um avanço na compreensão dessa estratégia, ele ainda planejava algumas de suas ações de forma intuitiva. Na 14a jogada da primeira partida, João falou sua estratégia de jogada com Lucas, que concordou. João pegou o -10 para não ceder o 15 à dupla adversária. Não fez boa jogada, pois perdeu 10 pontos e não percebeu que, se os outros pegassem o 15, eles poderiam depois pegar o 7, fazer os adversários pegarem o-2 e lhes ceder o 10.

Algo que começou a aparecer com mais freqüência no procedimento de jogar de Lucas foi a observação das ações do adversário. Em muitos momentos do jogo, Lucas comentou qual era a estratégia que o adversário pretendia usar. Na 7a jogada da primeira partida, enquanto a dupla adversária planejava sua jogada, Lucas disse para o parceiro: "João, já sei o que eles estão pensando", e mostrou a jogada. Duas estratégias novas surgiram enquanto Lucas fazia dupla com João. Uma delas foi blefar uma jogada; ele falava alto para o adversário que estava dando certo o que planejou, uma forma de desestabilizar a jogada do outro. Lucas disse: "ainda temos uma carta na manga, não é João?". A outra estratégia foi esconder as peças adquiridas para que o adversário não soubesse quantos pontos ele tinha.

Na dupla com João, Lucas voltou a fazer o cancelamento das peças de valor negativo com as de valor positivo. Em alguns momentos, ele cancelava uma peça de número negativo com uma outra positiva de mesmo valor e, em outros, ele cancelava o valor da soma dos números negativos com a mesma quantia de valor positivo. Fez essas operações, às vezes, durante a partida, outras após o final.

Ao final do processo de interação dessa dupla, Lucas continuou avançando em suas estratégias e seus procedimentos de jogar, mas ainda encontrava-se no nível II. Apesar do nível de compreensão não ter se alterado, Lucas sempre evoluiu em algum aspecto.

Na terceira dupla foi formada por Lucas e Guido. Na interação dessa dupla houve pouca cooperação entre os parceiros. Lucas jogou praticamente sozinho; era ele quem planejava e executava as jogadas. Uma estratégia que se tornou mais constante foi procurar perder menos pontos e ceder menos pontos ao adversário. Isso já havia acontecido nas duplas formadas anteriormente, mas nesse momento se tornou uma preocupação mais freqüente. Ao planejar sua estratégia, ele esteve atento às possibilidades de jogada do outro e analisou todas elas para jogar. Na 4a jogada do adversário na primeira partida, após jogar, Lucas falou com Guido:"de qualquer jeito, se eles pegarem um número positivo, a gente vai pegar um número alto". O adversário falou: "é?", ao que Lucas respondeu: "é mesmo, se você pegar o 5, a gente pega o 15; se pegar o 3, a gente pega o 10".

Lucas continuou a oscilar entre proteger o $15 \mathrm{e}$ perder mais pontos; e também entre conseguir perceber isso e prescindir desta estratégia. Utilizou muito a estratégia de colocar o adversário em uma fileira com peças negativas e algumas positivas, sendo que as positivas Ihe proporcionariam números positivos altos 
na próxima jogada. Continuou a blefar sobre uma jogada, agora com mais freqüência. No início da última partida, Lucas e o adversário discutiram, e parece que isso o deixou nervoso e o afetou, pois nas jogadas seguintes ele cedeu vários números altos, demonstrando não ter planejado suas ações considerando sua antecipação. Sempre que Lucas era provocado, isso interferia em seu modo de jogar.

Apesar de Lucas planejar suas jogadas utilizando, quase sempre, duas antecipações, em alguns momentos isso não acontecia, e ele apenas fazia uma antecipação futura. Em muitas situações, ele reconhecia o erro, mas a compreensão ainda não antecedia a ação. Na 9a jogada da primeira partida, havia dois números 10 na fileira, de maneira que um deles deixaria a outra dupla em uma situação melhor que o outro. Lucas pegou o 10, que deixaria o adversário na situação melhor, realizando apenas uma antecipação. Mais tarde, enquanto o adversário jogava, comentou com o parceiro: "era para eu ter pego o outro (10), né?"

Nessa dupla, Lucas realizou a contagem das peças praticamente sozinho. Ele continuou a fazer o cancelamento das peças de números negativos com positivos, mas não cancelava mais a soma dos números negativos, e sim, eliminava cada peça de valor negativo com uma outra positiva de mesmo valor. Essa operação foi feita, na maioria das vezes, durante a partida. Também, em grande parte, já fez a contagem de quantos pontos tinha durante a partida. Lucas fez a contagem das peças positivas uma a uma, e utilizou o auxílio dos dedos em alguns momentos.

Apesar dessas oscilações, Lucas parecia estar em um período de transição para o nível III de compreensão do sistema lógico do jogo. Em muitos momentos da partida, já utilizava estratégias e procedimentos deste nível.

Na terceira etapa, caracterizada pela resolução de situações-problema, Lucas fez parceria com Dario. Nela, Lucas realizou de duas a três antecipações, analisou todas as possibilidades de suas jogadas e do próximo jogador. Possuía a estratégia de pegar mais pontos, mesmo que para isso cedesse número alto. Apesar do progresso em sua compreensão do sistema do jogo, Lucas ainda não havia alcançado o nível III, permanecendo no nível II, pois, em alguns momentos, não antecipava adequadamente todas as ações por dedução.
Pela análise da partida realizada na quarta etapa, avaliou-se que Lucas apresentava, em seu procedimento, características do nível III de compreensão do sistema lógico contido no jogo Matix, pois analisava todas as suas jogadas, baseando-se sempre na relação entre as peças da coluna e da linha. Em várias jogadas, pegou pontos menores ou negativos para não deixar o adversário pegar um número de pontos maiores, mas nesse momento parecia conseguir compreender quando isso Ihe era vantajoso ou não, pois em nenhuma dessas jogadas ele perdeu ponto. Realizou jogadas com duas ou mais antecipações. Na 20a jogada do adversário, após este pegar o 0, Lucas fez gestos de excitação e, logo depois, de vitória. Enquanto o adversário jogava, planejou sua jogada posterior, considerando a intencionalidade e utilizando três antecipações futuras. Pegou o 2 e fez o outro pegar -10 e, logo depois, pegou o 5. Antes de fazer essa última ação, disse: "o jogo vai acabar", pois não havia mais números na fileira.

Com essa jogada, Lucas demonstrou que, além de ter realizado três antecipações, também criou a estratégia de fazer o adversário pegar -10 e acabar com o jogo, porque com isso ele ganharia a partida.

Lucas contou, durante todo o jogo, quantos pontos ele e o adversário tinham. Procurou fazer o cancelamento das peças de valor negativo conforme as pegava. Continuou a realizar a contagem das peças positivas uma a uma e a utilizar o auxílio dos dedos em alguns momentos.

Além das estratégias já vistas, parece que ele esperava uma oportunidade de acabar o jogo quando estivesse com mais pontos que o adversário, para, com isso, poder ganhar. Assim, pela análise das estratégias e dos procedimentos dessa partida, verificou-se que Lucas conseguiu avançar em sua compreensão do sistema lógico do jogo Matix e atingiu o nível III.

\section{Discussão}

Foi objeto deste trabalho analisar o funcionamento cognitivo de cada participante, caracterizado pela utilização de estratégias e de procedimentos em um processo de interação social de crianças e em um contexto de competição e de não competição, mas resta a questão: será que o processo de interação social de crianças em díades contribui para o progresso dos 
procedimentos e das estratégias cognitivas de cada participante para jogar o Matix? Os resultados obtidos na pesquisa parecem indicar que sim. Mas essas crianças também teriam avançado se tivessem passado por um outro processo que não envolvesse a interação com pares?

Todas as formas de interação que apareceram neste trabalho (duplas de crianças em situação de competição, duplas de crianças em situação de não-competição e duplas de adulto com criança) puderam intervir neste processo. Piaget (1924/1967) ressaltou que é por meio do compartilhamento social do pensamento que pode ocorrer o confronto de pensamentos de uns com os outros e, com isso, produzirem-se dúvidas e a necessidade de provar, possibilitando, assim, o desenvolvimento do raciocínio lógico.

Um dos pontos de conexão entre o campo das interações sociais de crianças e o desenvolvimento cognitivo observado no trabalho mostra que o progresso cognitivo parece estar associado às condições cognitivas de cada sujeito e à possibilidade de sua interrelação com os parceiros. Pelos dados obtidos nesta pesquisa, avaliou-se que as duas condições se fazem importantes para um avanço nas estratégias cognitivas. Perret-Clermont (1984) considera que é necessário a criança ter alcançado um nível de competência cognitiva para que a participação em uma situação de interação social ocasione nela um progresso em seu desenvolvimento.

Para ocorrer um deslocamento cognitivo é necessária uma participação mais efetiva do sujeito na interação com seu parceiro. Parece que não basta apenas observar o desempenho do outro; é preciso acompanhá-lo, compreendê-lo, interagir com o parceiro, para que isso tenha um efeito. Isso pode ser percebido a partir dos dados obtidos por meio da análise microgenética do funcionamento cognitivo do participante Guido. Ele conseguiu progredir em suas estratégias cognitivas, principalmente, no processo de interação com João, no qual ele atuou e cooperou mais. Piaget (1935/1998) apontou que a criança não é um ser que somente recebe informações prontas; ela é ativa e precisa interagir com seu meio social para que possa se desenvolver. Segundo La Taille (1992, citado por Moro, 1998), nem todo tipo de relação interindividual solicita cipantes, devido à existência permanente de relações de coação entre as de cooperação.

O aspecto afetivo pode interferir nas realizações cognitivas mais eficazes. Verificou-se isso no participante Lucas, que, após ter sido provocado pelo adversário, desestruturou-se e realizou vários procedimentos inadequados. Parece existir uma interdependência entre os aspectos afetivos e os cognitivos para se jogar bem. Segundo Moro (2000, p.308), quando crescem entre nossas situações as marcas afetivas naquelas interrelações, podem predominar soluções menos adiantadas. Estas ganham características de soluções afetivorelacionais, as quais chegam a perturbar ou a inibir a expressão, a estabilização de soluções cognitivas pelos parceiros.

Outro ponto que se pôde perceber, por meio do modo de atuação do participante João, é que jogar em dupla parece intensificar a possibilidade de descentração do pensamento por parte dos participantes. João, na primeira etapa da pesquisa, assim como na quarta etapa, nas quais jogou sozinho com a experimentadora, não conseguiu se descentrar de seu próprio jogo, não considerando a interdependência entre as suas ações e as do adversário, o que existiu quando ele jogou em dupla. A possibilidade de descentração de suas próprias ações diante das dos parceiros é referida na literatura (Moro, 2000), além de o próprio Piaget (1998) ter apontado que é pela cooperação que a criança pode abandonar um modo único de perceber as coisas.

\section{Considerações Finais}

Ao procurar alcançar as metas deste trabalho, ocorreram algumas constatações que ultrapassavam os objetivos propostos, por isso não foram aprofundadas. No entanto, é importante expô-las para possibilitar novos questionamentos e possíveis pesquisas.

Com relação aos níveis de análise utilizados para avaliar a compreensão dos participantes no sistema lógico contido no jogo Matix, observou-se que eles não são suficientemente adequados para verificar os progressos dos procedimentos e estratégias cognitivas obtidos. Os resultados da pesquisa indicam ser necessária a criação de subníveis para melhor adequação deste progresso, pois verificou-se que, apesar de os participantes se encontrarem no mesmo nível de com- 
preensão, eles conseguiram um avanço que precisaria ser contemplado.

Nesta pesquisa, três participantes permaneceram no mesmo nível de compreensão do sistema lógico do jogo, de acordo com os níveis propostos. Mas, pela análise microgenética realizada, na qual se pôde acompanhar a construção das estratégias cognitivas desses participantes, constatou-se que alguns as possuem mais avançadas do que outros.

Outro questionamento produzido a partir dos dados da pesquisa foi se a interação criança-criança proporcionaria maiores ganhos do que a interação adulto-criança. De fato, percebeu-se que a interação nas duplas de crianças mostrou-se mais eficaz do que a interação adulto-criança. Como exemplo, cita-se o participante Dario, que, ao jogar novamente com a experimentadora, não conseguiu apresentar as mesmas estratégias e os mesmos procedimentos que vinha tendo no momento de interação com seus parceiros.

Portanto, há espaço para estudos da interação adulto-criança, como também da participação do adulto na interação das crianças.

Por meio dos resultados obtidos, pôde-se comprovar que a análise microgenética se mostrou eficiente para o estudo das interações sociais de crianças e de suas estratégias cognitivas utilizadas para jogar o Matix.

Por fim, avaliou-se que o ambiente de jogos de regras mostrou-se um campo fértil para o estudo da interação de crianças. Verificou-se que o contexto de jogo propiciou a manifestação de diversas formas de relações entre os participantes e que essas relações contribuíram para o avanço da compreensão do sistema lógico contido no jogo.

\section{Referências}

Cavalcante, C. M. B., Ortega, A. C., \& Rodrigues, M. M. P. (2006). A interação social de crianças no jogo de regras. Arquivos Brasileiros de Psicologia, 57 (1-2), 28-45.

Doise, W., \& Mugny, G. (1981). Le développement social de l'intelligence. Paris: InterEditions.
Gilly, M., Fraisse, J., \& Roux, J.-P. (1992). Resolución de problemas en díadas y progresos cognitivos en niños de 11 a 13 años: Dinámicas interactivas y mecanismos sociocognitivos. In A.-N. Perret-Clermont \& M. Nicolet (Orgs.), Interactuar y conocer (pp.71-90). Buenos Aires: Miño y Dávila Editores.

Inhelder, B., \& Cellérier, G. (Orgs.). (1996). O desenrolar das descobertas da criança: um estudo sobre as microgêneses cognitivas. Porto Alegre: Artes Médicas.

Marco, F. F. (2004). Estudo dos processos de resolução de problema mediante a construção de jogos computacionais de matemática no ensino fundamental. Dissertação de mestrado não-publicada, Universidade Estadual de Campinas.

Moro, M. L. F. (1987). Aprendizagem operatória: a interação social da criança. São Paulo: Cortez, Autores Associados.

Moro, M. L. F. (1991). Crianças com crianças aprendendo: interação social e construção cognitiva. Cadernos de Pesquisa, 79, 31-43.

Moro, M. L. F. (1998). Aprendizagem construtivista da adição/ subtração e interações sociais: o percurso de três parceiros. Tese para Concurso de Professor Titular, Universidade Federal do Paraná, Curitiba.

Moro, M. L. F. (2000). A epistemologia genética e a interação social de crianças. Psicologia: Reflexão e Crítica, 13 (2), 295-310.

Perret-Clermont, A.-N. (1984). La construcción dela inteligencia en la interacción social: aprendiendo con los compañeros. Madrid: Visor Libros.

Petty, A. L. S. (1995). Ensaio sobre o valor pedagógico dos jogos de regras: uma perspectiva construtivista. Dissertação de mestrado não-publicada, Universidade de São Paulo.

Piaget, J. (1967). O raciocínio na criança. Rio de Janeiro: Record. (Originalmente publicado em 1924).

Piaget, J. (1973). Estudos sociológicos. Rio de Janeiro: Forense. (Originalmente publicado em 1945).

Piaget, J. (1998). Observações psicológicas sobre o trabalho em grupo. In S. Parrat \& A. Tryphon (Orgs.), Jean Piaget: sobre a pedagogia (pp.137-151). São Paulo: Casa do Psicólogo. (Originalmente publicado em 1935).

Torres, M. Z. (2003). Oraciocínio lógico-matemático de crianças no jogo Matix. Manuscrito não-publicado, Instituto de Psicologia, Universidade de São Paulo.

Torres, M.Z. (2005). Processos de regulação de crianças nojogo Matix. Manuscrito não-publicado, Instituto de Psicologia, Universidade de São Paulo.

Recebido em: 5/1/2007

Versão final reapresentada em: 20/6/2007

Aprovado em: 15/8/2007 